\title{
PERAN PERTAMBANGAN TERHADAP PENGEMBANGAN WILAYAH KABUPATEN TANGGAMUS PROVINSI LAMPUNG
}

\author{
The Role of Mining on Regional Development of Tanggamus, \\ Lampung Province
}

\section{Wicaksono Tri Wuryanto ${ }^{1}$, Kukuh Murtilaksono ${ }^{2}$ dan Boedi Tjahjono ${ }^{2}$}

\begin{abstract}
Abstrak: Penelitian ini bertujuan untuk menganalisis peran sektor pertambangan terhadap perekonomian wilayah, menganalisis perubahan luasan penggunaan lahan tahun 2000-2015, serta menyusun arahan rencana pengembangan wilayah pertambangan di Kabupaten Tanggamus. Metode yang digunakan dalam penelitian ini meliputi analisis input output dengan agregasi dan RAS, klasifikasi citra satelit, dan teknik tumpang tindih peta. Sektor pertambangan lebih bersifat forward oriented yang memiliki kemampuan dalam mendorong sektor di depannya bertumbuh dibandingkan dengan kemampuannya untuk menarik sektor yang ada di belakangnya. Perubahan penggunaan lahan di Kabupaten Tanggamus dari tahun 2000 sampai 2015 mengalami dinamika yang cukup tinggi. Lahan pertanian mengalami perubahan yang terbesar yaitu menjadi lahan terbangun sebesar 5168 ha. Pada lokasi pertambangan, penggunaan lahan yang paling besar laju pertumbuhannya adalah lahan terbangun sebesar 265.74 ha per tahun. Hasil identifikasi pemanfaatan fungsi kawasan untuk aktifitas penambangan menunjukkan bahwa 6.03\% kawasan lindung dan 8.05\% kawasan budidaya dimanfaatkan sebagai areal tambang. Rekomendasi alokasi kawasan peruntukan pertambangan diarahkan pada areal dalam izin usaha pertambangan dengan luas sebesar 20773.82 ha.
\end{abstract}

Kata kunci: pertambangan, perubahan penggunaan lahan, review rencana tata ruang wilayah

\begin{abstract}
This research aims to analyze the role of the mining sector to the regional economy, analyzing the change of land use $2000-2015$, as well as preparing the development plan direction of mining area in Tanggamus Regency. The methods used in this study include analysis of input output with aggregation and RAS, satellite image classification, and overlapping map techniques. The mining sector is more forward-oriented that has the ability to push the sector ahead of it to grow compared to its ability to attract the existing sector behind it. Changes in land use in Tanggamus District from 2000 to 2015 are dynamics. The most changing land is agricultural land turned into developed land of 5168 ha. At the mining site, the largest land use growth rate is developed land $265.74 \mathrm{ha} /$ year. Identification result of area function utilization for mining activity shows that $6.03 \%$ of protected areas and $8.05 \%$ of cultivation areas utilized as mining area. Recommendations is the allocation of mining designated areas shall be directed to the area in the mining business permit of 20773.82 ha.
\end{abstract}

Keywords:land use change,mining, review of regional spatial plan

\footnotetext{
${ }^{1}$ Magister Ilmu Perencanaan Wilayah, Fakultas Pertanian, Institut Pertanian Bogor

${ }^{2}$ Departemen Ilmu Tanah dan Sumberdaya Lahan, Fakultas Pertanian, Institut Pertanian Bogor
} 


\section{PENDAHULUAN}

Kabupaten Tanggamus merupakan salah satu daerah yang terus membangun dan belakangan ini tampak mengandalkan sektor pertambangan dalam struktur perekonomiannya. Distribusi Produk Domestik Regional Bruto (PDRB) Kabupaten Tanggamus tahun 2015 didominasi oleh sektor pertanian $(45.40 \%)$, sedangkan urutan berikutnya adalah sektor perdagangan (9.17\%) dan sektor pertambangan $(6.83 \%)$ (BPS Kabupaten Tanggamus 2016). Semakin bertambahnya investasi di bidang pertambangan telah meningkatkan pendapatan daerah. Hal ini dibuktikan dari PDRB Kabupaten Tanggamus yang meningkat dari sektor pertambangan pada periode tahun 2012-2015 berturut-turut sebesar 490169 milyar rupiah, 551492 milyar rupiah, 652991 milyar rupiah, dan 759124 milyar rupiah (BPS Kabupaten Tanggamus 2016). Pada tahun 2014 sektor pertambangan dan penggalian mencatatkan pertumbuhan ekonomi tertinggi kedua, yakni sebesar 10.07 persen, di bawah sektor jasa perusahaan (12.44\%) (BPS Kabupaten Tanggamus 2015). Hal ini menunjukkan bahwa sektor pertambangan berperan penting dalam meningkatkan kinerja perekonomian Kabupaten Tanggamus.

Sektor pertambangan dan sektor lainnya memiliki peran penting dalam menopang perekonomian Kabupaten Tanggamus. Oleh karena itu kajian tentang peran sektor pertambangan dalam perekonomian Kabupaten Tanggamus diperlukan mengingat sektor pertambangan di Kabupaten Tanggamus sangat berperan sebagai salah satu pembentuk terbesar PDRB. Dalam hal ini sektor pertambangan harus ditingkatkan agar mampu menarik sektor-sektor di hulu dan di hilirnya. Semakin kuat keterkaitan sektor pertambangan dengan sektor-sektor lain, maka akan makin besar pula pengaruhnya terhadap perkembangan wilayah Kabupaten Tanggamus.

Jumlah izin pertambangan yang ada di wilayah Kabupaten Tanggamus saat ini sebanyak 24 izin dengan jumlah cadangan sumberdaya mineral sebesar 152831928 ton (Kementerian ESDM 2015). Pemberian izin pertambangan kepada pihak swasta merupakan salah satu upaya pemerintah untuk memperoleh manfaat dari sumberdaya bahan tambang, serta pajak dan royalti. Hal tersebut diharapkan akan memberi kontribusi terhadap pertumbuhan ekonomi wilayah. Hal ini diperkuat oleh hasil penelitian dari Nurhayaty (2013) yang menyatakan bahwa karena pemenuhan pendapatan daerah, maka pemerintah daerah berani mengeluarkan izin pertambangan sebanyak-banyaknya agar pendapatan minimal daerah terpenuhi.

Selama ini kebijakan pemerintah terkait pemanfaatan dan pengelolaan sumberdaya bahan tambang masih memprioritaskan keuntungan secara ekonomi. Kerusakan lingkungan yang diakibatkan oleh kegiatan pertambangan tampaknya masih diabaikan oleh pemerintah, padahal lingkungan merupakan aset penting yang harus dipertahankan agar dapat memenuhi kebutuhan dasar masyarakat untuk jangka panjang.

Faktor lokasi tambang memiliki dampak besar pada perubahan penggunaan lahan di semua tipe tutupan lahan. Apalagi terdapat akses-akses baru yang dibuka dan perubahan penggunaan lahan tidak dapat diawasi sehingga memperparah kondisi lingkungan yang ada. Dalam hal ini luas lokasi tambang memiliki dampak yang nyata terhadap perubahan kawasan hutan menjadi lahan terbuka serta kawasan pemukiman/bangunan (Hidayat 2015).

Rencana Tata Ruang Wilayah (RTRW) merupakan instrumen yang sangat baik untuk mengendalikan perubahan tata guna lahan (Pribadi et al. 2006). Oleh karenanya untuk pengelolaan lingkungan di Kabupaten Tanggamus perusahaan-perusahaan tambang harus diakomodir dengan baik ke dalam RTRW Kabupaten Tanggamus, karena aktivitas-aktivitas tambang yang terbuka menyebabkan terjadinya perubahan tutupan/penggunaan lahan (Tuni 2013). 
Jumlah luas areal pertambangan di Kabupaten Tanggamus saat ini mencapai 20773 ha sedangkan luas kawasan peruntukan pertambangan pada RTRW Kabupaten Tanggamus periode 2011-2031 hanya dialokasikan sebesar 4725 ha. Hal tersebut mengindikasikan bahwa telah terjadi penyimpangan pemanfaatan fungsi kawasan di Kabupaten Tanggamus.

Untuk mengantisipasi dampak lebih lanjut dari inkonsistensi penataan ruang di atas, maka perlu adanya pemantauan perubahaan tutupan/penggunaan lahan, prediksi tutupan/penggunaan lahan, dan kesesuaian peruntukan ruang agar rencana tata ruang wilayah dapat tercapai sesuai dengan harapan dan dapat memberikan kontribusi terhadap pengembangan wilayah di Kabupaten Tanggamus.

Penelitian ini bertujuan untuk mengkaji :1) peran sektor pertambangan terhadap perekonomian wilayah di Kabupaten Tanggamus, 2) perubahan luasan tutupan/penggunaan lahan di Kabupaten Tanggamus tahun 2000-2015, dan 3) arahan rencana pengembangan wilayah pertambangan di Kabupaten Tanggamus.

\section{METODE PENELITIAN}

Penelitian ini dilaksanakan di Kabupaten Tanggamus yang mencakup 20 Kecamatan pada Bulan Agustus 2016 sampai Juni 2017. Data yang digunakan berupa data sekunder dan data primer. Data sekunder dikumpulkan dari berbagai instansi sesuai dengan substansi yang akan dikaji. Data primer diperoleh dari cek lapang berupa penutupan lahan serta wawancara dengan penduduk lokal. Hubungan tujuan penelitian, jenis data, sumber data, dan teknis analisis dapat dilihat pada Tabel 1.

Tabel 1. Tujuan Penelitian, Jenis Data, Sumber Data, dan Teknik Analisis Data

\begin{tabular}{|c|c|c|c|c|}
\hline Tujuan & Jenis data & Sumber data & $\begin{array}{c}\text { Teknik analisis } \\
\text { data }\end{array}$ & Output \\
\hline $\begin{array}{l}\text { Menganalisis peran } \\
\text { sektor pertambangan } \\
\text { terhadap } \\
\text { perekonomian } \\
\text { wilayah dan } \\
\text { keterkaitannya } \\
\text { dengan sektor-sektor } \\
\text { lain }\end{array}$ & $\begin{array}{l}\text { - Tabel Input Output (I-O) } \\
\text { Provinsi Lampung tahun } \\
2010 \\
\text { - PDRB Provinsi Lampung } \\
\text { tahun 2010-2015 } \\
\text { - PDRB Kabupaten } \\
\text { Tanggamus tahun 2010- } \\
2015\end{array}$ & $\begin{array}{l}\text {-BPS Provinsi } \\
\text { Lampung } \\
\text { •BPS Kab. } \\
\text { Tanggamus }\end{array}$ & $\begin{array}{l}\text { - Agregasi } \\
\text { - RAS } \\
\text { - Analisis Input } \\
\text { Output (I-O) }\end{array}$ & $\begin{array}{l}\text { Informasi } \\
\text { tentang nilai } \\
\text { keterkaitan } \\
\text { antar sektor } \\
\text { di Kabupaten } \\
\text { Tanggamus }\end{array}$ \\
\hline $\begin{array}{l}\text { Menganalisis } \\
\text { perubahan luasan } \\
\text { tutupan/penggunaan } \\
\text { lahan di Kabupaten } \\
\text { Tanggamus tahun } \\
\text { 2000-2015 }\end{array}$ & $\begin{array}{l}\text { - Citra landsat ETM } 7 \\
\text { tahun 2000, 2005, } 2010 \text {, } \\
2015 \\
\text { - Citra SPOT tahun } 2015 \\
\text { - Peta administrasi Kab. } \\
\text { Tanggamus } \\
\text { - Peta RTRW Kabupaten } \\
\text { Tanggamus tahun 2011- } \\
\text { 2031 }\end{array}$ & $\begin{array}{l}\text {-BAPPEDA } \\
\text { Kab. } \\
\text { Tanggamus } \\
\text {-Kementerian } \\
\text { LHK } \\
\text {-BIG }\end{array}$ & $\begin{array}{l}\text { Klasifikasi } \\
\text { tutupan/ } \\
\text { penggunaan } \\
\text { lahan }\end{array}$ & $\begin{array}{l}\text { Peta dan } \\
\text { matriks } \\
\text { perubahan } \\
\text { tutupan/ } \\
\text { penggunaan } \\
\text { lahan tahun } \\
2000,2005, \\
2010 \text { dan } 2015\end{array}$ \\
\hline $\begin{array}{l}\text { Menyusun arahan } \\
\text { rencana } \\
\text { pengembangan } \\
\text { wilayah } \\
\text { pertambangan di } \\
\text { Kabupaten } \\
\text { Tanggamus }\end{array}$ & $\begin{array}{l}\text { - Peta pola ruang wilayah } \\
\text { Kabupaten Tanggamus } \\
\text { tahun } 2011-2031 \\
\text { - Peta sebaran tambang }\end{array}$ & $\begin{array}{l}\text { - BAPPEDA } \\
\text { Kab. } \\
\text { Tanggamus } \\
\text { - Kementerian } \\
\text { ESDM }\end{array}$ & $\begin{array}{l}\text { Overlay peta } \\
\text { pola ruang } \\
\text { dengan peta } \\
\text { sebaran tambang }\end{array}$ & $\begin{array}{l}\text { Arahan } \\
\text { rencana } \\
\text { pengembangan } \\
\text { wilayah } \\
\text { pertambangan } \\
\text { di Kabupaten } \\
\text { Tanggamus }\end{array}$ \\
\hline
\end{tabular}




\section{Analisis Input-Output (I-0)}

Tabel I-O Kabupaten Tanggamus tahun 2015 diperoleh dari updating tabel I-O Provinsi Lampung tahun 2010 yang diturunkan melalui metode RAS, yaitu suatu metode updating tabel I-O yang dibuat berdasarkan matriks koefisien teknologi (koefisien input). RAS merupakan sebuah nama rumus matriks yang dikembangkan oleh Richard Stone, dimana $\mathrm{R}$ dan $\mathrm{S}$ adalah matriks diagonal berukuran $\mathrm{n} \times \mathrm{n}$ yang menunjukkan banyaknya sektor industri (Daryanto dan Hafizrianda 2010). Selanjutnya dilakukan analisis untuk mengetahui peran sektor pertambangan melalui keterkaitan sektor baik secara langsung ke belakang (direct backward linkage) maupun ke depan (direct forward linkage) dengan sektor lainnya, Indeks Daya Penyebaran (IDP) dan Indeks Derajat Kepekaaan (IDK) serta melalui multiplier effect (efek ganda) yang ditimbulkannya, baik efek ganda output (output multiplier), Nilai Tambah Bruto (value added multiplier) maupun pendapatan (income multiplier).

\section{Analisis Perubahan Tutupan/Penggunaan Lahan}

Analisis untuk mendeteksi perubahan tutupan/penggunaan lahan dilakukan dengan cara menumpangtindihkan (overlay) peta penutupan/penggunaan lahan menggunakan metode klasifikasi citra dengan pendekatan klasifikasi terbimbing. Tutupan lahan dibagi menjadi 8 tipe yaitu : hutan, kebun campuran, lahan terbangun/permukiman, perkebunan, sawah, semak belukar/lahan terbuka, tambak dan tubuh air. Skala peta yang digunakan adalah 1:100 000, hasil klasifikasi kemudian diuji kebenarannya. Klarifikasi dilakukan dengan dua cara, pertama melakukan cek pada citra dengan resolusi tinggi (SPOT), kedua dengan melakukan pengecekan ke lapang secara langsung. Hasil dari interpretasi ini adalah peta penutupan/penggunaan lahan Kabupaten Tanggamus tahun 2000, 2005, 2010, dan 2015. Selanjutnya dibuat matriks transisi untuk mengetahui pola perubahan penggunaan lahan pada setiap periode pengamatan, yaitu tahun 2000-2005, 2005-2010, dan 2010-2015.

\section{Analisis OverlayPeta}

Arahan pengembangan wilayah pertambangan dilakukan dengan melakukan operasi tumpang tindih (overlay) peta rencana tata ruang wilayah (RTRW) Kabupaten Tanggamus dengan peta sebaran tambang. Arahan pengembangan wilayah pertambangan yang dijadikan acuan adalah areal yang telah dialokasikan sebagai kawasan peruntukan pertambangan dalam peta RTRW dan areal yang telah terdapat izin usaha pertambangan.

\section{HASIL DAN PEMBAHASAN}

\section{Peran Sektor Pertambangan terhadap Perekonomian Kabupaten Tanggamus}

Berdasarkan hasil analisis Input-Output (IO) keterkaitan 17 sektor ekonomi di Kabupaten Tanggamus (Tabel 2) didapatkan bahwa sektor pertambangan memiliki nilai keterkaitan langsung ke belakang atau DBL (direct backward linkage) sebesar 0.327 dan nilai DFL (direct forward linkage) atau keterkaitan langsung ke depan sebesar 1.247. Ini berarti sektor pertambangan lebih bersifat forward oriented yang mengindikasikan bahwa sektor tersebut mampu mendorong sektor di depannya dibandingkan dengan kemampuannya untuk menarik sektor yang ada di belakangnya.

Berdasarkan nilai Indeks Daya Penyebaran (IDP) dan Indeks Derajat kepekaan (IDK) sektor pertambangan memiliki nilai 0.792 dan 1.051. Artinya bahwa sektor pertambangan secara relatif kurang mampu menarik sektor-sektor hulunya namun memiliki kemampuan 
untuk mendorong sektor-sektor hilir yang menggunakan outputnya sebagai input produksi. Terdapat 2 (dua) sektor kunci karena memiliki nilai IDP dan IDK yang tinggi ( $>1$ ) yakni sektor industri pengolahan dan sektor transportasi dan pergudangan. Adapun, sektor pertambangan masuk ke dalam kategori sektor pendukung bagi sektor kunci, karena memiliki nilai IDP yang rendah namun mempunyai nilai IDK yang tinggi.

Tabel 2. Hasil analisis input output sektor-sektor perekonomian di Kabupaten Tanggamus

\begin{tabular}{|c|c|c|c|c|c|}
\hline $\begin{array}{l}\text { KODE } \\
\text { IO }\end{array}$ & SEKTOR & DBL & DFL & IDP & IDK \\
\hline 1 & Pertanian, Kehutanan dan Perikanan & 0,58 & 2,60 & 0.86 & 1.60 \\
\hline 2 & Pertambangan dan Penggalian & 0,33 & 1,25 & 0.79 & 1.05 \\
\hline 3 & Industri Pengolahan & 1,18 & 2,60 & 1.03 & 1.44 \\
\hline 4 & Pengadaan Listrik dan Gas & 1,79 & 0,81 & 1.20 & 0.91 \\
\hline 5 & Pengadaan Air, Pengelolaan Sampah, Limbah dan daur ulang & 0,69 & 0,07 & 0.93 & 0.71 \\
\hline 6 & Kontruksi & 1,53 & 0,22 & 1.16 & 0.76 \\
\hline 7 & $\begin{array}{l}\text { Perdagangan Besar dan Eceran, Reparasi Mobil dan Sepeda } \\
\text { Motor }\end{array}$ & 0,78 & 2,74 & 0.94 & 1.52 \\
\hline 8 & Transportasi dan Pergudangan & 1,27 & 1,47 & 1.09 & 1.14 \\
\hline 9 & Penyediaan Akomodasi dan Makan Minum & 1,24 & 0,57 & 1.05 & 0.85 \\
\hline 10 & Informasi dan Komunikasi & 0,96 & 1,46 & 0.99 & 1.14 \\
\hline 11 & Jasa Keuangan dan Asuransi & 0,47 & 0,59 & 0.83 & 0.88 \\
\hline 12 & Real Estate & 0,55 & 1,36 & 0.87 & 1.09 \\
\hline 13 & Jasa Perusahaan & 1,01 & 0,25 & 1.00 & 0.77 \\
\hline 14 & $\begin{array}{l}\text { Administrasi Pemerintahan, Pertahanan dan Jaminan Sosial } \\
\text { Wajib }\end{array}$ & 0,77 & 0,33 & 0.94 & 0.78 \\
\hline 15 & Jasa Pendidikan & 1,01 & 0,23 & 1.00 & 0.75 \\
\hline 16 & Jasa Kesehatan dan Kegiatan Sosial & 1,48 & 0,26 & 1.14 & 0.77 \\
\hline 17 & Jasa lainnya & 1,38 & 0,21 & 1.12 & 0.76 \\
\hline
\end{tabular}

Keterangan: $D B L=$ Direct Backward Linkage, DFL $=$ Direct Forward Linkage, IDP $=$ Indeks Daya Penyebaran, IDK = Indeks Derajat Kepekaan

Berdasarkan Tabel 3, jika dilihat Income Multiplier (IM), sektor pertambangan menempati urutan 12 dengan nilai IM sebesar 0.14, yang artinya bahwa apabila permintaan akhir sektor pertambangan meningkat satu rupiah, maka dampak terhadap pendapatan wilayah akan meningkat 0.14 rupiah. Hal ini menunjukkan bahwa sektor pertambangan kurang berkontribusi dalam hal pembentukan pendapatan rumah tangga di Kabupaten Tanggamus. Sektor pertambangan memiliki dampak paling tinggi terhadap Nilai Tambah Bruto/NTB dengan nilai Value Added Multiplier (VM) sebesar 0.85 yang berarti bahwa apabila permintaan akhir sektor pertambangan meningkat satu rupiah, maka dampak terhadap NTB akan meningkat 0.85 rupiah. Keberadaan sektor pertambangan sangat berpengaruh dan memberikan dampak yang sangat besar terhadap nilai tambah bruto di wilayah Kabupaten Tanggamus. Jika dilihat dari output multiplier (OM), sektor pertambangan menempati peringkat 7 dengan nilai 1.50. Nilai ini dapat diartikan bahwa apabila permintaan akhir sektor pertambangan meningkat sebesar satu rupiah, maka diperkirakan output perekonomian wilayah meningkat sebesar 1.50 rupiah. Peningkatan permintaan akhir sektor pertambangan tersebut berdampak pada peningkatan output sektor lainnya. 
Tabel 3. Hasil analisis multiplier effect sektor-sektor perekonomian di Kabupaten Tanggamus tahun 2015

\begin{tabular}{|c|c|c|c|c|c|c|c|}
\hline \multirow{2}{*}{$\begin{array}{l}\text { KODE } \\
\text { IO }\end{array}$} & \multirow[b]{2}{*}{ SEKTOR } & \multicolumn{2}{|c|}{ IM } & \multicolumn{2}{|c|}{ VM } & \multicolumn{2}{|c|}{$\mathrm{OM}$} \\
\hline & & Nilai & $\begin{array}{l}\text { Peringk } \\
\text { at }\end{array}$ & $\begin{array}{c}\text { Nila } \\
\text { i }\end{array}$ & $\begin{array}{l}\text { Peringk } \\
\text { at }\end{array}$ & $\begin{array}{c}\text { Nila } \\
\text { i }\end{array}$ & $\begin{array}{l}\text { Peringk } \\
\text { at }\end{array}$ \\
\hline 1 & Pertanian, Kehutanan dan Perikanan & 0.15 & 11 & 0.73 & 4 & 2.29 & 1 \\
\hline 2 & Pertambangan dan Penggalian & 0.14 & 12 & 0.85 & 1 & 1.50 & 7 \\
\hline 3 & Industri Pengolahan & 0.14 & 13 & 0.45 & 11 & 2.06 & 3 \\
\hline 4 & Pengadaan Listrik dan Gas & 0.03 & 17 & 0.17 & 17 & 1.30 & 8 \\
\hline 5 & $\begin{array}{l}\text { Pengadaan Air, Pengelolaan Sampah, } \\
\text { Limbah dan daur ulang }\end{array}$ & 0.40 & 2 & 0.68 & 5 & 1.03 & 17 \\
\hline 6 & Kontruksi & 0.10 & 16 & 0.29 & 16 & 1.10 & 12 \\
\hline 7 & $\begin{array}{l}\text { Perdagangan Besar dan Eceran, } \\
\text { Reparasi Mobil dan Sepeda Motor }\end{array}$ & 0.18 & 6 & 0.64 & 6 & 2.19 & 2 \\
\hline 8 & Transportasi dan Pergudangan & 0.17 & 8 & 0.38 & 13 & 1.64 & 4 \\
\hline 9 & $\begin{array}{l}\text { Penyediaan Akomodasi dan Makan } \\
\text { Minum }\end{array}$ & 0.15 & 10 & 0.42 & 12 & 1.23 & 10 \\
\hline 10 & Informasi dan Komunikasi & 0.12 & 15 & 0.55 & 8 & 1.64 & 5 \\
\hline 11 & Jasa Keuangan dan Asuransi & 0.23 & 5 & 0.78 & 2 & 1.26 & 9 \\
\hline 12 & Real Estate & 0.13 & 14 & 0.75 & 3 & 1.57 & 6 \\
\hline 13 & Jasa Perusahaan & 0.18 & 7 & 0.53 & 10 & 1.10 & 13 \\
\hline 14 & $\begin{array}{l}\text { Administrasi Pemerintahan, Pertahanan } \\
\text { dan Jaminan Sosial Wajib }\end{array}$ & 0.57 & 1 & 0.64 & 7 & 1.12 & 11 \\
\hline 15 & Jasa Pendidikan & 0.30 & 3 & 0.53 & 9 & 1.08 & 16 \\
\hline 16 & Jasa Kesehatan dan Kegiatan Sosial & 0.24 & 4 & 0.31 & 15 & 1.10 & 14 \\
\hline 17 & Jasa lainnya & 0.17 & 9 & 0.36 & 14 & 1.10 & 15 \\
\hline
\end{tabular}

Keterangan: $I M=$ Income Multiplier, VM = Value Added Multiplier, OM = Output Effect Multiplier

Berdasarkan seluruh indikator keterkaitan dan multiplier effect melalui analisis $\mathrm{I}-\mathrm{O}$ maka diketahui bahwa sektor pertambangan belum termasuk sektor strategis karena menurut Rustiadi et al. (2011) sektor strategis adalah sektor yang memiliki keterkaitan ke depan dan ke belakang yang besar serta mampu menciptakan angka pengganda (multiplier) yang besar dalam perekonomian. Indikator tersebut kontradiktif dengan besarnya potensi dan sumbangan sektor pertambangan yang dimiliki terhadap PDRB dan nilai tambah bruto di Kabupaten Tanggamus.

Upaya yang dapat dilakukan dalam mewujudkan sektor pertambangan sebagai salah satu sektor strategis di Kabupaten Tanggamus adalah meningkatkan keterkaitan dengan sektor-sektor lain. Dengan memiliki keterkaitan yang kuat terhadap sektor industri non migas diharapkan sektor pertambangan akan menjadi sektor strategis yang bisa meningkatkan perekonomian wilayah Kabupaten Tanggamus. Yanti et al. (2013) menyatakan bahwa implementasi otonomi daerah merupakan momentum dalam pengembangan sektor-sektor ekonomi lokal. Pengembangan sumberdaya daerah yang dimiliki menjadi produk unggulan dengan daya saing komparatif dan kompetitif merupakan agenda strategis pembangunan daerah.

\section{Dinamika Perubahan Penggunaan Lahan di Kabupaten Tanggamus}

Hasil klasifikasi penggunaan lahan di Kabupaten Tanggamus pada periode tahun 2000-2015 yang paling dominan secara luasan adalah kebun campuran dengan luas mencapai 218304 ha pada tahun 2000 dengan persentase pada periode 2000-2015 berkisar antara $76.16 \%$ sampai $77.58 \%$ dari luas daratan Kabupaten Tanggamus. Penggunaan lahan lain yang cukup dominan adalah hutan yang memiliki luasan 33088 ha 
pada tahun 2000 dengan persentase pada periode 2000-2015 berkisar antara $11.23 \%$ sampai $11.59 \%$. Selanjutnya adalah luas lahan terbangun, sawah, dan semak belukar $(2 \%-$ $6 \%$ ), sedangkan lahan perkebunan dan tambak hanya memiliki persentase luas masingmasing di bawah satu persen dari keseluruhan wilayah. Dinamika perubahan penggunaan lahan Kabupaten Tanggamus tahun 2000-2015 disajikan pada Tabel 4, dan sebaran spasial hasil interpretasi penggunaan lahan Kabupaten Tanggamus disajikan Gambar 1.

Tabel 4 Luas tipe tutupan/penggunaan lahan di Kabupaten Tanggamus tahun 2000-2015

\begin{tabular}{lrrrrr}
\hline \multirow{2}{*}{ Penggunaan lahan } & \multicolumn{5}{c}{ Luas (ha) } \\
\cline { 2 - 6 } & \multicolumn{1}{c}{2000} & \multicolumn{1}{c}{2005} & \multicolumn{1}{c}{2010} & \multicolumn{1}{c}{2015} & \multicolumn{1}{c}{ Perubahan } \\
\hline Hutan & 33088.70 & 33088.74 & 32586.34 & 32070.80 & -1017.98 \\
Kebun campuran & 218304.28 & 218189.16 & 217474.16 & 221535.19 & 3231.10 \\
Lahan terbangun & 2756.17 & 2756.17 & 3319.63 & 8447.54 & 5691.36 \\
Perkebunan & 330.37 & 330.37 & 330.37 & 468.38 & 138.01 \\
Sawah & 12913.20 & 12915.17 & 15388.74 & 14854.90 & 1941.62 \\
Semak belukar & 17140.30 & 17140.27 & 15261.25 & 6980.37 & -10159.95 \\
Tambak & 109.91 & 223.05 & 282.44 & 285.75 & 175.84 \\
Tubuh air & 903.07 & 903.07 & 903.07 & 903.07 & 00.00 \\
\hline Jumlah & 285546.00 & 285546.00 & 285546.00 & 285546.00 & \\
\hline
\end{tabular}

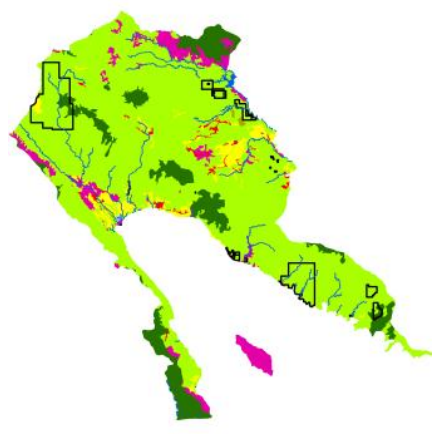

a) Tahun 2000

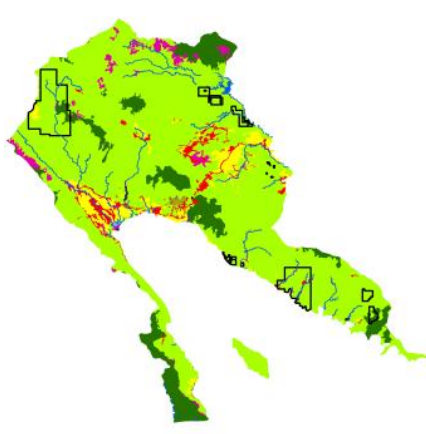

d) Tahun 2015

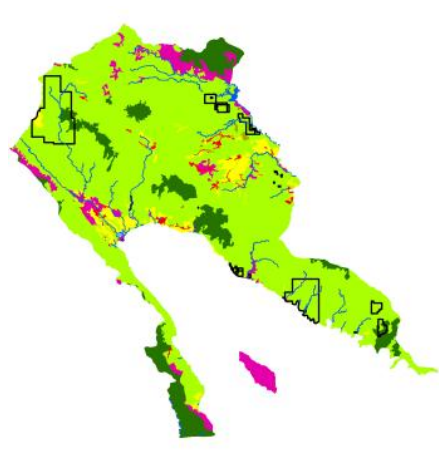

b) Tahun 2005

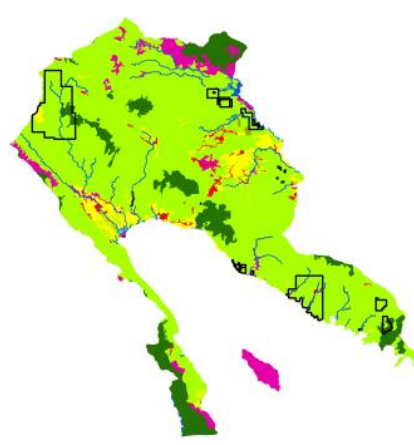

c) Tahun 2010

Keterangan

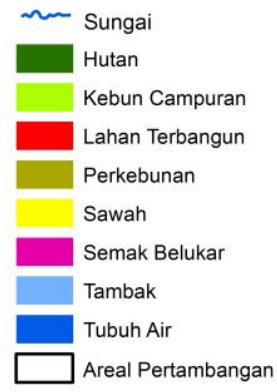

Areal Pertambangan

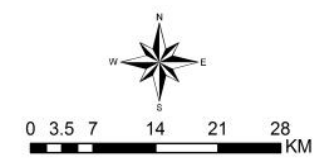

Gambar 1 Hasil interpretasi penggunaan lahan Kabupaten Tanggamus tahun 2000-2015 
Kabupaten Tanggamus pada periode tahun 2000-2015 mengalami perubahan penggunaan lahan yang sangat dinamis. Penggunaan lahan yang paling besar perubahannya adalah lahan terbangun yang luasannya bertambah 5691.36 ha hasil konversi dari lahan kebun campuran, sawah, dan semak belukar. Sedangkan semak belukar lahan hutan mengalami penurunan yaitu masing-masing sebesar 10159.95 ha dan 1017.98 ha.

Luas lahan terbangun dan kebun campuran cenderung mengalami kenaikan dengan rata-rata laju peningkatan masing-masing sekitar 379.42 ha per tahun dan 215.41 ha per tahun. Hal ini terjadi karena kebutuhan lahan baik untuk tempat tinggal (sebagai konsekuensi pertumbuhan penduduk) maupun untuk lahan pertanian semakin meningkat karena kebutuhan pangan meningkat setiap tahunnya.

Terkait lokasi pertambangan, sebagian besar berada pada penggunaan lahan kebun campuran (18 614.66 ha) dan hutan (1 289.67 ha). Berdasarkan Tabel 5 terlihat bahwa pada periode 2000-2015 penggunaan lahan yang paling besar perubahannya adalah lahan terbangun dan semak belukar pertambahan luas lahan terbangun merupakan hasil konversi lahan kebun campuran dan semak belukar dengan laju pertumbuhan sebesar 265.74 ha atau 17.72 ha per tahun, sedangkan pertambahan semak belukar merupakan hasil konversi lahan hutan dan kebun campuran dengan laju pertumbuhan sebesar 59.74 ha. Hal ini dipertegas oleh Sihombing (2013) yang menyatakan bahwa perubahan tutupan/penggunaan lahan hutan terjadi karena terdapat deposit energi dan mineral yang berlimpah di suatu wilayah sedangkan tipe lahan terbangun/permukiman mengalami peningkatan karena adanya kebutuhan masyarakat untuk bermukim.

Tabel 5 Laju perubahan penggunaan lahan di lokasi pertambangan Kabupaten Tanggamus tahun 2000-2015

\begin{tabular}{lrrrr}
\hline \multirow{2}{*}{ Penggunaan lahan } & \multicolumn{2}{c}{ Luas (ha) } & \multicolumn{2}{c}{ Laju perubahan } \\
\cline { 2 - 5 } & Tahun 2000 & Tahun 2015 & Luas (ha) & Laju/Tahun (ha) \\
\hline Hutan & 1289.67 & 1193.42 & -96.25 & -6.42 \\
Kebun campuran & 18614.66 & 18376.03 & -238.63 & -15.91 \\
Lahan terbangun & 0.00 & 265.74 & 265.74 & 17.72 \\
Sawah & 788.97 & 791.03 & 2.06 & 0.14 \\
Semak belukar & 75.35 & 135.09 & 59.74 & 3.98 \\
Tambak & 0.00 & 6.53 & 6.53 & 0.44 \\
Tubuh air & 5.17 & 5.98 & 0.81 & 0.05 \\
\hline
\end{tabular}

\section{Pengembangan Wilayah Pertambangan di Kabupaten Tanggamus}

Hasil operasi tumpang tindih (overlay) antara peta Rencana Tata Ruang Wilayah (RTRW) Kabupaten Tanggamus dan peta izin pertambangan dapat diidentifikasi bahwa telah terjadi penyimpangan pemanfaatan fungsi kawasan. Areal pertambangan yang tidak sesuai dengan fungsi kawasan peruntukan pertambangan pada pola ruang adalah sebesar 19994.12 ha atau 96.25\% dari jumlah areal pertambangan (20 $773.82 \mathrm{ha}$ ), sedangkan areal pertambangan yang sesuai dengan fungsi kawasan peruntukan pertambangan hanya sebesar 779.70 ha atau $3.75 \%$ dari jumlah luas areal pertambangan. Penyimpangan pemanfaatan fungsi kawasan secara spasial ditunjukkan pada Gambar 2.

Dari hasil pemetaan terlihat bahwa lokasi pertambangan berada dalam kawasan lindung sebesar 8984.83 ha atau $6.03 \%$ dari total luas kawasan lindung, pada kawasan budidaya sebesar 11009.28 ha atau 8.05\% dari total luas kawasan budidaya (diluar kawasan peruntukan pertambangan). Agar tidak terjadi banyak penyimpangan maka dibutuhkan perubahan luas kawasan peruntukan pertambangan pada RTRW Kabupaten 
Tanggamus yang mempertimbangkan aspek informasi daerah deposit tambang. Hal ini dapat mempertegas batasan wilayah yang diperbolehkan sebagai wilayah pertambangan sehingga dapat menengahi permasalahan sektoral yang berkaitan dengan persaingan pemanfaatan ruang.

Berdasarkan Peraturan Daerah Kabupaten Tanggamus Nomor 16 dijelaskan bahwa wilayah-wilayah yang sudah diketahui cadangannya dan/atau wilayah yang tengah dalam masa eksplorasi/eksploitasi dan secara legal telah ada izin atau kontraknya maka harus dilindungi secara hukum di dalam tata ruang sebagai kawasan peruntukan pertambangan. Selain itu wilayah yang berpotensi menyimpan bahan tambang harus diberikan alokasi ruang dalam bentuk wilayah prospek usaha pertambangan yang tidak dipengaruhi oleh kendala sektor budi daya atau lindung lainnya, namun dalam pengusahaannya tetap mengikuti ketentuan perundang-undangan yang berlaku.

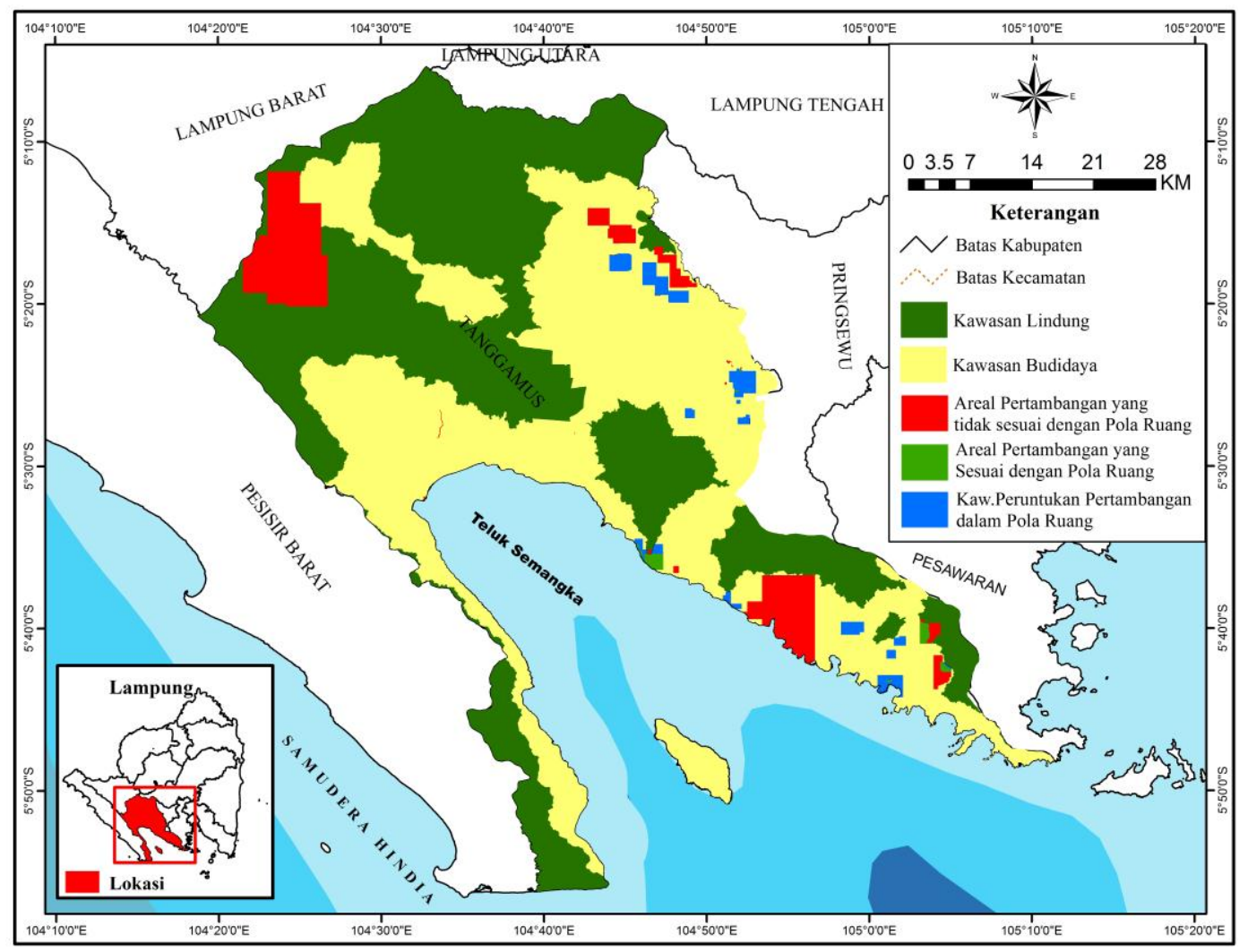

Gambar 2 Penyimpangan pemanfaatan fungsi kawasan di Kabupaten Tanggamus

Hasil analisis ini memberikan ruang bagi aktifitas pertambangan yang diarahkan sebagai kawasan peruntukan pertambangan untuk menghindari alokasi yang tumpang tindih dalam pemanfaatan ruang kawasan. Alokasi kawasan peruntukan pertambangan diarahkan pada areal pada izin usaha pertambangan dengan luas sebesar 20773.82 ha seperti yang disajikan pada Gambar 3.

Untuk kawasan lindung yang telah menjadi areal pertambangan diarahkan sebagai kawasan peruntukan pertambangan namun dalam pengusahaannya dilakukan dengan pola pertambangan bawah tanah dan tidak mengubah fungsi pokok kawasan secara permanen, hal tersebut sesuai dengan Peraturan Pemerintah Nomor 24/2010. Selain itu pelaku usaha dikenakan kewajiban menyediakan lahan kompensasi di luar kawasan hutan untuk 
dijadikan kawasan hutan dengan rasio 1:2. Dengan demikian, keberadaan kawasan lindung sebagai salah satu sistem penyangga kehidupan dapat dipertahankan secara optimal dengan luasan yang cukup agar daya dukungnya tetap lestari.

Dampak lingkungan akibat kegiatan pertambangan antara lain: penurunan produktivitas lahan, terjadinya erosi dan sedimentasi, terjadinya gerakan tanah atau longsor, serta terganggunya flora dan fauna. Kegiatan pertambangan mengakibatkan penurunan kualitas lingkungan yang terdiri dari polusi udara, penurunan debit air dan polusi suara sebesar Rp.1 972833514 (fachlevi 2015), sehingga disarankan kepada pemerintah daerah dalam memberikan izin usaha pertambangan perlu dipertimbangkan nilai-nilai manfaat jasa lingkungan yang memberikan manfaat secara berkelanjutan, karena nilai tambang hanya memberikan manfaat untuk pertumbuhan ekonomi dalam jangka pendek.

Berdasarkan Peraturan Pemerintah Nomor 78/2010, pelaku usaha pertambangan diwajibkan melakukan kegiatan reklamasi sedini mungkin dan tidak harus menunggu proses pertambangan selesai dilakukan secara keseluruhan. Dalam upaya pemberdayaan lahan pasca tambang yang produktif, dapat dilakukan sesuai keinginan dari masyarakat sekitar, dan keterlibatan pemerintah daerah sebagai lembaga yang memberi ijin dan fasilitas, serta rencana pengembangan wilayah terutama kebijakan tata ruang, dan pihak swasta lainnya yang berperan sebagai investor.

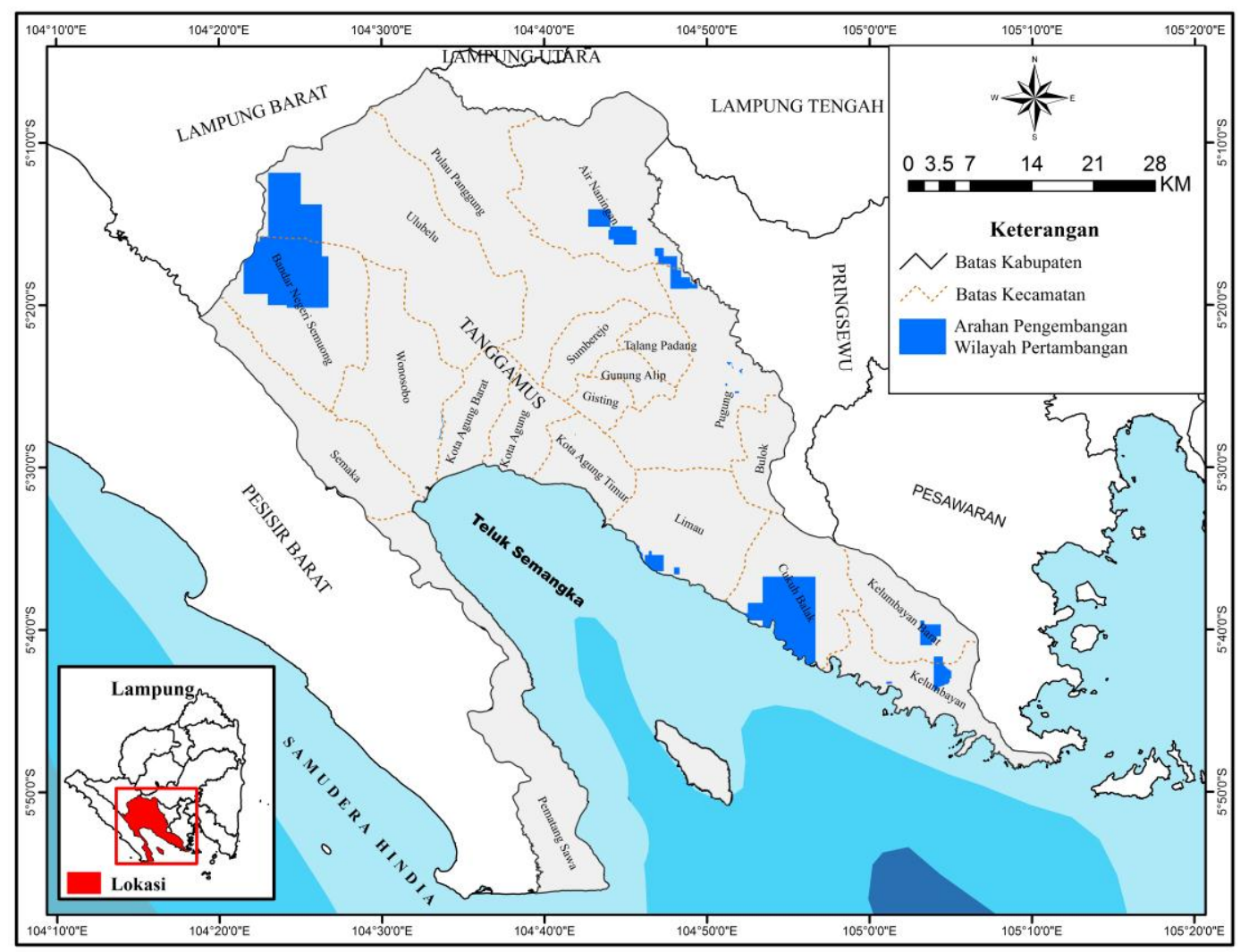

Gambar 3 Arahan pengembangan wilayah pertambangan di Kabupaten Tanggamus

Sebagian lahan bekas tambang di Indonesia dimanfaatkan untuk pertanian, perikanan, peternakan, sumber air baku dan sebagainya. Henny (2011) menyebutkan 
bahwa pemanfaatan lahan bekas tambang yang telah dilakukan antara lain untuk sumber air minum; sumber air bersih untuk mandi cuci; perikanan (sistem kolam jaring apung dan tebar); peternakan bebek peking; dan pariwisata. Hasil penelitian papua (2008) menyatakan bahwa pengembangan pariwisata pada kawasan bekas tambang berdampak positif terhadap konservasi dan pelestarian lingkungan hidup, penciptaan lapangan kerja, peningkatan pendapatan masyarakat sekitar kawasan, dan turut membangun Pendapatan Asli Daerah (PAD), serta tidak ditemukan dampak negatif terhadap budaya masyarakat sekitar kawasan.

Dalam melakukan pengendalian pemanfaatan ruang terdapat empat instrumen yang dapat digunakan untuk menjaga konsistensi dalam pemanfaatan ruang. Adapun keempat instrumen tersebut adalah sebagai berikut: (1 peraturan zonasi, penyimpangan dalam perencanaan yakni dialihfungsikannya sebagian kawasan hutan lindung, kawasan sekitar waduk, dan kawasan pertanian sawah sebagai kawasan peruntukan pertambangan haruslah dikembalikan fungsinya sebagaimana seharusnya yakni sebagai kawasan lindung dan kawasan persawahan. (2 pemberian izin, setiap perizinan usaha pertambangan harus mempunyai izin prinsip, izin lingkungan yang terkait dengan izin lokasi/fungsi ruang, kualitas ruang, dan pengendalian ketat (high controlled zone) yang diatur lebih lanjut dalam peraturan daerah. (3 insentif dan disinsentif, pemberian insentif dalam bentuk keringanan pajak dan kompensasi terhadap kegiatan yang sejalan dengan tata ruang. Pemberian disinsentif dalam bentuk pengenaan pajak tinggi, pembatasan akses dalam penyediaan infrastruktur, penalti untuk aktivitas pemanfaatan ruang yang tidak sejalan dengan tata ruang. ( 4 pengenaan sanksi administratif ataupun sanksi pidana diberikan untuk setiap aktivitas pemanfaatan ruang yang tidak sesuai dengan tata ruang, pelanggaran peraturan zonasi, pemanfaatan ruang yang tidak memiliki izin, dan pemanfatan ruang yang menghalangi akses terhadap kepentingan umum.

\section{KESIMPULAN}

Sektor pertambangan merupakan sektor kunci dalam penciptaan nilai tambah bruto (NTB) karena memiliki nilai pengganda NTB tertinggi diantara sektor lainnya, tetapi sektor pertambangan belum termasuk sektor strategis di Kabupaten Tanggamus karena keterkaitan dengan sektor-sektor lainnya relatif rendah sehingga belum mampu meningkatkan pertumbuhan ekonomi terutama pada sektor hulunya.

Pada periode tahun 2000-2015 penggunaan lahan yang paling besar peningkatan luasannya di Kabupaten Tanggamus secara umum maupun pada lokasi areal pertambangan adalah lahan terbangun dengan rata-rata laju peningkatan di Kabupaten Tanggamus sebesar 379.42 ha per tahun dan 17.72 ha per tahun pada lokasi areal pertambangan.

Pengembangan wilayah pertambangan diarahkan pada areal izin pertambangan seluas 20773.82 ha dengan mengubah kawasan lindung dan kawasan budidaya lainnya menjadi kawasan peruntukan pertambangan seluas 19994.12 ha atau 96.25\% dari jumlah areal pertambangan di Kabupaten Tanggamus. Terdapat empat instrumen yang dapat digunakan untuk menjaga konsistensi dalam pemanfaatan ruang, yaitu: peraturan zonasi, pemberian izin, pemberian insentif dan disinsentif, serta pengenaan sanksi. 


\section{DAFTAR PUSTAKA}

[BPS] Badan Pusat Statistik Kabupaten Tanggamus. 2015. Produk Domestik Regional Bruto Kabupaten Tanggamus Menurut Lapangan Usaha Tahun 2010 - 2014. Kota Agung (ID): Badan Pusat Statistik Kabupaten Tanggamus

[BPS] Badan Pusat Statistik Kabupaten Tanggamus. 2016. Tanggamus Dalam Angka 2015. Kota Agung (ID): Badan Pusat Statistik Kabupaten Tanggamus.

Daryanto A, Hafizrianda Y. 2010. Analisis Input-Output dan Social Accounting Matrix untuk Pembangunan Ekonomi Daerah. Bogor: IPB Press.

Fachlevi TA. 2015. Dampak dan Evaluasi Kebijakan Pertambangan Batubara di Kecamatan Mereubo. Risalah Kebijakan Pertanian dan Lingkungan. 2(2): 171-180.

Henny C. 2011. "Kolong” bekas tambang timah di Pulau Bangka: permasalahan kualitas air dan alternatif solusi untuk pemanfaatan. Oseanologi dan Limnologi di Indonesia. 37(1): 119-138. Pusat Penelitian Limnologi. LIPI

Hidayat W. 2015. Dampak Pertambangan Terhadap Perubahan Penggunaan Lahan dan Kesesuaian Peruntukan Ruang (Studi Kasus Kabupaten Luwu Timur, Provinsi Sulawesi Selatan). Jurnal Perencanaan Wilayah dan Kota. 26(2): 130-146.

Nurhayaty SL. 2013. Tinjauan Yuridis Penyelesaian Sengketa Tumpang Tindih Lahan Pertambangan Migas dan Batubara. Jurnal Beraja Niti 2(10): 1-25.

Papua HMA. 2008. Potensi kawasan bekas tambang sebagai objek wisata (Studi kasus Kandi-Tanah Hitam Kota Sawahlunto) [Tesis]. Bogor (ID): Institut Pertanian Bogor.

Pribadi DO, Shiddiq D, Ernyanila M. 2006. Model perubahan tutupan lahan dan faktor-faktor yang mempengaruhi. Jurnal teknologi lingkungan 7(1): 35-51. P3TL-BPPT.

Rustiadi E, Panuju DR, Saifulhakim S. 2011. Perencanaan dan pengembangan wilayah. Jakarta (ID): Crestpent press yayasan pustaka obor Indonesia.

[Setda] Sekretariat Daerah Kabupaten Tanggamus. 2011. Peraturan Daerah Kabupaten Tanggamus Nomor 16 Tentang Rencana Tata Ruang Wilayah Kabupaten Tanggamus Tahun 2011-2031. Kota Agung (ID): Setda Kabupaten Tanggamus.

[Setneg] Sekretariat Negara Republik Indonesia. 2010. Peraturan Pemerintah Republik Indonesia Nomor 24 Tahun 2010 Tentang Penggunaan Kawasan Hutan. Jakarta (ID): Setneg.

[Setneg] Sekretariat Negara Republik Indonesia. 2010. Peraturan Pemerintah Republik Indonesia Nomor 78 Tahun 2010 Tentang Reklamasi dan Pascatambang. Jakarta (ID): Setneg.

Sihombing BH. 2013. Analisis perubahan tutupan lahan areal konsesi tambang PT.Kaltim Prima Coal. IImu Pertanian dan Kehutanan. 11(2):83-89.

Tuni MS. 2013. Prediksi Perubahan Tutupan Lahan dan Perencanaan Peggunaan Lahan Pascatambang Nikel di Kabupaten Halmahera Timur. Globe. 15(2): 146-152.

Yanti TS, Rohaeni O, Astuti F. 2013. Menentukan Analisis Industri Unggulan di Kota Bandung Menggunakan Indeks Komposit. Statistika 13(2):73 - 79. 